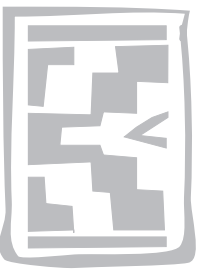

\title{
Seasonal evolution of faecal egg output by gastrointestinal worms in goats on communal farms in eastern Namibia
}

\author{
F.F. KUMBA ${ }^{1 *}$, H. KATJIVENA ${ }^{2}$, G. KAUTA ${ }^{2}$ and E. LUTAAYA ${ }^{1}$
}

\begin{abstract}
KUMBA, F.F., KATJIVENA, H., KAUTA, G. \& LUTAAYA, E. 2003. Seasonal evolution of faecal egg output by gastrointestinal worms in goats on communal farms in eastern Namibia. Onderstepoort Journal of Veterinary Research, 70:265-271

As a more detailed continuation of a previous study, faecal samples for worm egg counts were collected per rectum from ten marked adult animals in selected flocks of goats, in each of six villages evenly spread out in the communal farming district of Okakarara in eastern Namibia. The study was conducted on a monthly basis from August 1999 to July 2000. Average faecal worm egg counts (FECs) were highest during the warm-wet season, much lower during the cold-dry months and moderate during the hot-dry season. Least square means of FECs were 2140,430 and 653 per gram of faeces for the three seasons, respectively. Seasonal variation in egg counts was significant $(P<$ 0.0001). Gastrointestinal strongyles, and to a lesser extent Strongyloides species, were the predominant parasite groups identified in goats. Kidding rates peaked in the cold-dry season and mortality rates in the hot-dry season. Results of this study suggest that gastrointestinal parasitism may be a problem that accentuates the effect of poor nutrition on small ruminants during the season of food shortages in the east of Namibia and that the use of FECs per se to assess the severity of gastrointestinal parasitic infection in goats followed by chemoprophylactic strategic and/or tactical treatment, may not be the best approach to addressing the worm problem under resource-poor conditions. The use of the FAMACHAC system that identifies severely affected animals for treatment is technically a better option for communal farmers.
\end{abstract}

Keywords: Faecal egg counts, FAMACHAC system, gastrointestinal nematodes, goats, seasonal occurrence

\section{INTRODUCTION}

Infection by gastrointestinal parasites is one of the most serious problems affecting small ruminant populations worldwide (Pugh, Hilton \& Mobini 1998;

* Author to whom correspondence is to be directed

1 Department of Animal Science, Faculty of Agriculture and Natural Resources, University of Namibia, Private Bag 13301, Windhoek, Namibia

2 Farming Systems Research and Extension, Directorate of Research and Training, Ministry of Agriculture, Water and Rural Development, Private Bag 1437, Otjiwarongo, Namibia

Accepted for publication 12 May 2003-Editor
Waller 1999). In many parts of Africa heavy worm burdens have often been demonstrated in small ruminants (Connor, Munyuku, Mackyao \& Halliwell 1990; Huart, Dungu, Matatu \& Schandevyl 1993; Ndao, Belot, Zinsstag \& Pfister 1995; Vassilev 1995; Kusiluka, Kambarage, Harrison, Daborn \& Matthewman 1998; Ameh, Egwu \& Tijjani 2000). Goats are an important source of livelihood for smallholder farmers in southern Africa (Donkin \& Boyazoglu 2000) but appear especially vulnerable to the negative effects of gastrointestinal parasitism (Pomroy 1985; Radostitis, Blood \& Gay 1994). Tactical and strategic prophylactic treatments of flocks with anthelmintic preparations are measures recommended 
by parasitologists for the control of gastrointestinal parasites (Biggs \& Anthonissen 1982; Radostits et al. 1994; Vassilev 1995; Garcia-Perez, Hurtado, Oregui \& Juste 2002). For instance in the Basque country in Spain, two tactical annual treatments based on the physiological status of the animal and season have recently been recommended in dairy sheep (Garcia-Perez et al. 2002). Frequent tactical and strategic treatment is blamed for the emergence, in recent years, of rapid development of anthelmintic resistance to nearly all available drugs, posing serious threats to the small ruminant industry (Barton 1983; Rowlands, 1993; Boersema \& Pandey 1997; Van Wyk, Bath \& Malan 1998; Van Wyk, Stenson, Van der Merwe, Vorster \& Viljoen 1999; Van Wyk 2001). In southern Africa, most smallholder farmers in communal grazing areas are resource-poor, hence are often unable to pay for veterinary services including recommended tactical or strategic anthelmintic treatments. In Namibia, faecal egg count (FEC) is still the main technique used to determine the severity of gastrointestinal parasitic infection in livestock. Output of eggs by intestinal worms is known to fluctuate depending on various factors including the physiological status of the host animal (Pandey, Ndao \& Kumar 1994; Nuvor, Assoku \& Agyei 1997) and seasonal changes in local environmental conditions (Mukaratirwa, Hove \& Kyvsgaard 1997; Arosemena, Bevilaqua, Melo \& Girao 1999) besides, FEC is a highly specialized technique. The aim of this study was to determine the evolution of the parasitic burden in goats in the eastern communal area of Namibia and to recommend sustainable worm control protocols that are affordable and manageable by communal farmers themselves to estimate and combat parasitic infection in small ruminants. It is a continuation of a previous study of the same nature in the same area (Kumba, Undi, Katjivena, Kauta, Hengua \& Tjiteere 2000).

\section{MATERIALS AND METHODS}

\section{The study area}

This study was carried out in the district of Okakarara $\left(20^{\circ} 0^{\prime}-21^{\circ} 4^{\prime} \mathrm{S}\right.$; $17^{\circ} 30^{\prime}-18^{\circ} 25^{\prime} \mathrm{E}$, altitude $1050 \mathrm{~m}$ ), which forms part of the vast eastern communal agricultural area of Namibia. The area is semi-arid with an erratic annual rainfall of 250 $550 \mathrm{~mm}$ that is usually almost totally confined to the warm-wet season (January to April), although in the year of study, rainfall pattern deviated considerably from the usual norm. The mean minimum tempera- ture is low $\left(6^{\circ} \mathrm{C}\right)$ during May to September, the cold-dry season. By contrast the mean maximum temperature is high $\left(31^{\circ} \mathrm{C}\right)$ during October to December, the hot-dry season.

Okakarara district is sparsely populated, with most villages composed of just a few families. Cattle, goat and sheep farming constitute the main subsistence activity for the communal farmers but goats are the predominant species owned by the poorest farmers. All animals, especially small ruminants, in a particular village are exposed to the same environmental conditions because the same grazing land is communally utilized all year round. Significant demographic increases in recent years demanded that livestock numbers are increased to meet the nutritional needs of the rapidly increasing population in the eastern communal area. As a result, tremendous pressure is exerted on the limited grazing resource leading to overgrazing and seasonal shortages of animal feed, particularly during the hot-dry season. Frequent droughts have only added to the difficulty. The meteorological data for rainfall (1986-2000) and temperature (1999/2000) used in this study were obtained from a station in the neighbouring Omaruru communal farming district.

\section{Animals}

Six villages (Okatuhoro, Okanjokomukona, Omatupa, Oruvize, Otjimati and Otjiyere) were selected by virtue of their proximity to six points evenly marked on the district map. Herds of goats belonging to a randomly selected household in each village were used for the one-year study period. Households were selected from a list available at the district agricultural extension office at Okakarara but were included in the investigation if they were willing to participate, and had goat flocks that had not received any anthelmintic treatment within 12 months prior to commencement of the study. Selected farmers agreed not to deworm the goats or to dispose of any marked animal for the duration of the study. In total, selected households owned 425 adult goats at the beginning of the study, with between 12-96 goats per household. Of these 299 animals $(70 \%)$ were females and 126 animals (30\%) were males. Most flocks consisted of indigenous goat breeds or crosses of indigenous animals and Boer goats. For this study, ten adult animals, both males and females, randomly selected by the researchers within each flock, were earmarked by notching the left ear. No attempt was made to balance selected animals as regards to sex nor to distinguish if selected males were intact or castrated. 
Experimental animals were herded during the day and housed at night in unroofed kraals together with the rest of the flock, separate from other domestic species. In all goat flocks from which animals were selected for study, the owners agreed to keep record of newborn animals and animals that died due to disease or non-identified causes, such as loss in the veld. Seven experimental animals that died during the study were promptly replaced with animals randomly selected within the same flock.

\section{Parasitological analysis}

During the first week of each month, between August 1999 and July 2000, three faecal pellets (about 2-3 g) were collected, from the rectum of each experimental animal as described by Reinecke (1983). Faecal samples were pooled per flock in plastic bags, stored on ice in cold boxes and dispatched to the laboratory for composite FECs by the modified McMaster technique (Reinecke 1983). The collection of faecal samples in the field lasted for three days each month and sample analysis was completed within a week after delivery of samples to the laboratory. Samples were stored at $4{ }^{\circ} \mathrm{C}$ pending coprological analysis in the laboratory. Morphological features of parasite eggs were used to identify groups of parasites (Reinecke 1983; Urquhart, Armour, Duncan, Dunn \& Jennings 1996).

\section{Statistical analysis}

The data on average FECs was analyzed by the SAS GLM procedure (Anon. 1996). The model included influence of season (January to April $=1$, May to September $=2$, October to December $=3$ ) and village, where the latter was used as a blocking factor. In randomized complete block designs it is assumed that there is no interaction between treatments and blocks (Lentner \& Bishop 1993). However, in this study, samples were collected monthly from the same flock over any given season, hence constituting sub-samples. Thus a season $x$ village interaction was included in the model and was used to test the significance of the main effect (season).

Residual analysis indicated one outlying observation, which was dropped in subsequent analyses because the farmer in question may have predisposed his goats to greater risks of parasitic infection in a marshy area, in the search for pasture. The residual analysis also indicated a non-constant variance. Data was thus transformed using natural logarithms and this resulted in a better-fitting model. Least square means were tested for significance using the t-test, then back-transformed.

\section{RESULTS}

Average FECs in goats varied from one village to another, and from month to month in the same village (Table 1). The FECs followed a three-pronged trend, being highest in January, February, March and April (the warm-wet season) in most villages, much lower in May to September (the cold-dry season), and intermediate for October to December (the hot-dry months) (Fig. 1). As indicated in Fig. 2, the rainfall during the period of study was much greater than usual, with some unusually high downpours particularly in December. It is interesting to note the similarity in the pattern between rainfall and faecal egg output (Fig. 2 and 3). Strongyles

TABLE 1 Monthly average FECs per gram of faecal sample from goats in six selected villages in Okakarara district, eastern Namibia (August 1999 to July 2000). Note the very high egg count recorded at Oruvize in November. This was excluded from subsequent analyses

\begin{tabular}{|l|c|c|c|c|c|r|}
\hline Months & Okatuhoro & Okanjoko & Omatupa & Oruvize & Otjimati & Otjiyere \\
\hline Aug & 100 & 200 & 1300 & 800 & 900 & 200 \\
Sep & 100 & 100 & 400 & 600 & 900 & 300 \\
Oct & 700 & 700 & 1000 & 800 & 900 & 1200 \\
Nov & 1500 & 500 & 2400 & 10600 & 800 & 200 \\
Dec & 400 & 2000 & 2900 & 2100 & 2200 & 1300 \\
Jan & 200 & 3200 & 1800 & 1200 & 1800 & 200 \\
Feb & 2100 & 5100 & 1700 & 5500 & 2600 & 800 \\
Mar & 2500 & 5600 & 600 & 1900 & 7200 & 3600 \\
Apr & 1000 & 500 & 1200 & 1000 & 600 & 900 \\
May & 700 & 1400 & 100 & 1500 & 500 & 200 \\
Jun & 300 & 100 & 100 & 500 & 400 & 700 \\
Jul & 100 & & & & 400 \\
\hline
\end{tabular}




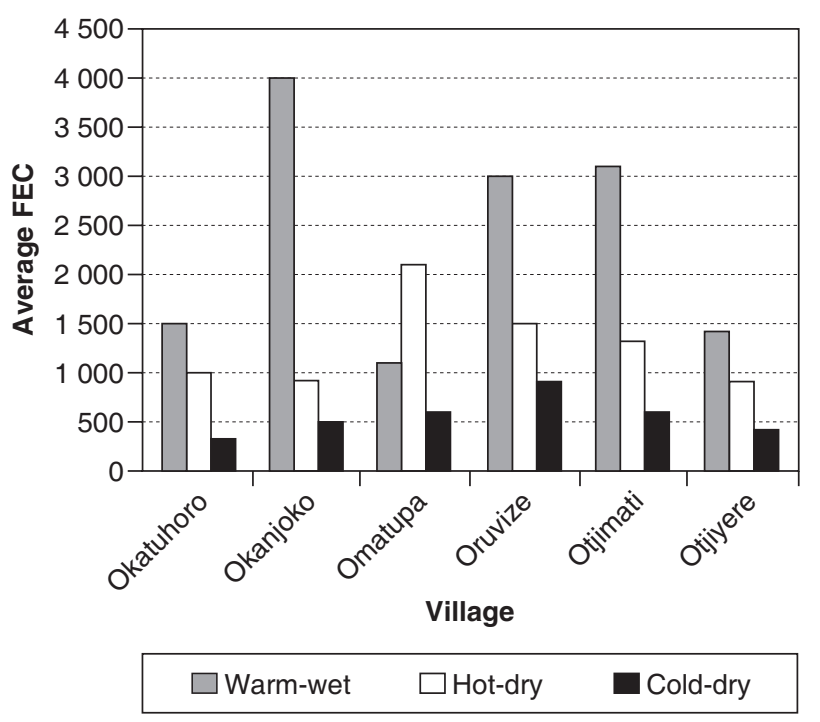

FIG. 1 Average seasonal FECs per gram of faecal sample from goats in six selected villages in Okakarara district, eastern Namibia (August 1999 to July 2000)

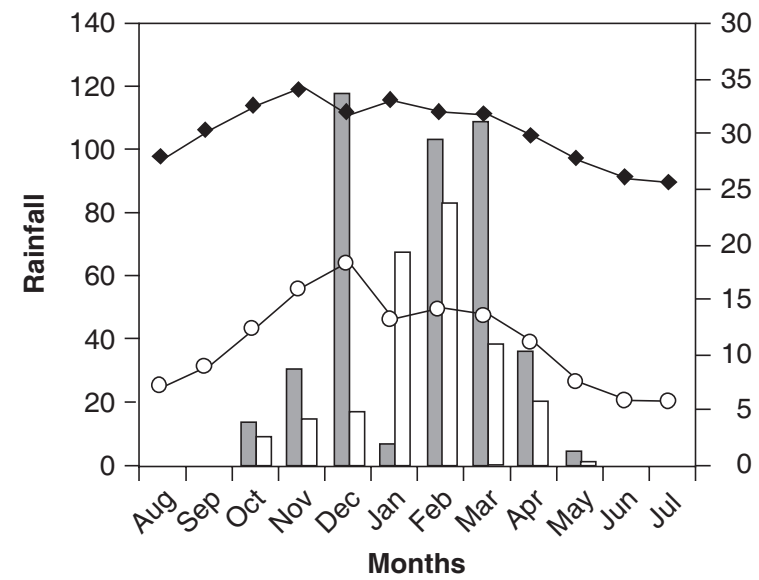

$\square$ Monthly rainfall 1999/2000

$\square$ Average monthly rainfall 1986-1999

- Mean maximum temperature 1999/2000

-o- Mean minimum temperature 1999/2000

FIG. 2 Mean minimum and maximum temperatures and rainfall as recorded at Omaruru in the eastern communal areas of Namibia (1999-2000) and the average monthly rainfall for the area during a 15-year period (1986-1999). Note that rainfall during period of study was higher than usual especially in December 1999

and to a lesser extent Strongyloides predominated during all seasons in all experimental flocks (Fig. 3). Other parasite eggs seen in one farm were those of ascarids. No trematode eggs were found, probably because of the unfavourable environment in the east of Namibia for the proliferation of their

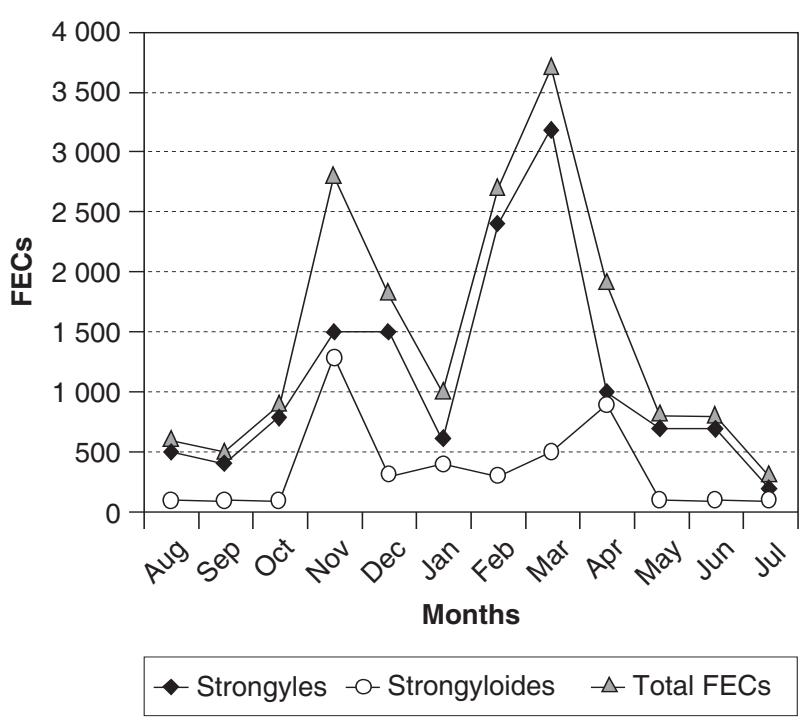

FIG. 3 Average monthly FECs per gram of faecal sample from goats in six villages in Okakarara district, eastern $\mathrm{Na}$ mibia (August 1999 to July 2000). Note that low FECs were recorded in May through September, the cold-dry season. It is obvious that Strongyles were the main parasite group found in goats in the area

molluscan intermediate hosts. The apparent absence of cestode eggs might be an indication that the flotation method used at the Grootfontein veterinary laboratory is not suitable for detection of cestode eggs.

Kidding peaked in June and declined gradually thereafter towards the end of the hot-dry season in December (Table 2). No newborn kids were reported during February-April. Table 2 also shows that mortalities occurred mostly among kids and $>80 \%$ of mortalities occurred in the cold-dry and hot-dry seasons (September to December), with almost no deaths occurring in the warm-wet season. Farmers were of the opinion that morbidity was lowest in the warm-wet season and relatively high in the other seasons, especially during the hot-dry months, and that the predominant clinical manifestations encountered were due to gastrointestinal helminth infection and intoxications attributed to plant poisoning. They described gastrointestinal parasitism as mainly sporadic conditions characterized by general poor body condition, emaciation and/or diarrhoea, often affecting few animals in flocks. Obviously some of these symptoms may be due to malnutrition with the exception that many more animals would be involved in the case of malnutrition. Plant poisoning on the other hand was described as acute conditions often resulting in rapid death. Many of the more prosperous farmers (not involved 
TABLE 2 The number of kids born as well as mortalities among young and adult goats due to disease and non-specific causes in all goat-flocks in which animals were selected for study during 1999-2000 in six villages in Okakarara district

\begin{tabular}{|l|l|l|l|l|}
\hline Month & No. of kids born & No. of kids died & No. of adults goats died & Total no. of animals died \\
\hline January & 2 & 9 & 0 & 9 \\
February & 0 & 2 & 0 & 2 \\
March & 0 & 1 & 0 & 1 \\
April & 0 & 0 & 0 & 0 \\
May & 0 & 2 & 0 & 0 \\
June & 93 & 3 & 7 & 9 \\
July & 64 & 4 & 2 & 5 \\
August & 75 & 18 & 9 & 5 \\
September & 26 & 25 & 6 & 27 \\
October & 46 & 12 & 7 & 33 \\
November & 33 & 96 & 7 & 19 \\
December & 19 & 35 & 131 \\
\hline Total & 358 & & & \\
\hline
\end{tabular}

in this study) in the communal area administered anthelmintic preparations to the more severely affected animals in their flocks.

Analysis of variance showed highly significant differences $(P<0.0001)$ in seasonal average FECs. An unusually high FEC was recorded in the flock at Oruvize during November (Table 1), probably because farmers in this village moved their animals to a neighbouring marshy area in search of better grazing. This abnormal record was excluded from the statistical analyses. Least square means of average FEC across all flocks were 2140, 430 and 653 for seasons 1,2 and 3 respectively, and were significantly different $(P<0.05)$.

\section{DISCUSSION AND CONCLUSIONS}

In this study the evolution of monthly FECs followed the well-known pattern influenced primarily by temperature and moisture (Biggs \& Anthonissen 1982; Radostits et al. 1994; Urquhart et al. 1996; Arosemena et al. 1999) as they were highest in the wet season (which is warm), moderate in the hot-dry season and lowest in the cold-dry season. It seems unlikely that the phenomenon of peri-parturient rise (Nuvor et al. 1997) could have played a role since the FECs were at their lowest levels when most kidding occurred. On the other hand, it is possible that the so-called spring rise in FEC [from maturation of hypobiotic $L_{4}$ larvae (Blitz \& Gibbs 1972)] may have been responsible for the observed rise in FECs before the rains came at the beginning of the warm-wet season. Another possibility is the early rains at some villages that may have had an influence. In the village of Oruvize very high average
FECs were recorded during November when the animals were grazed on marshy land (Table 1), probably due to the ample moisture that was available.

Many authors have reported Haemonchus spp. as of paramount importance in small ruminants in many parts of southern Africa, including Namibia (Biggs \& Anthonissen 1982; Pandey et al. 1994; Vassilev 1995; Vatta, Letty, Van der Linde, Van Wijk, Hansen \& Krecek 2001; Vatta, Krecek, Letty, Van der Linde, Grimbeek, De Villiers, Motswatswe, Molebiemang, Boshoff \& Hansen 2002), and these worms were probably also dominant in the present study. The observation of ascarid eggs in animals on one farm is probably a spurious occurrence, the eggs having been ingested by the animals during grazing. No record was found, indicating infection in goats by these parasites in southern Africa.

Mortality among goats was low during the warmwet season probably because grazing is abundant all over the communal farming area during this season. Well-fed animals have better resistance to parasites and most pathogens. In contrast, it seems likely that the relatively high mortality recorded during the hot-dry season resulted from a shortage of feed, common in the area at this time of the year, resulting in greater susceptibility to gastrointestinal parasites and other pathogens. The helminthes may have contributed to the mortality in combination with poor nutrition, but this was not investigated in this study. It should be kept in mind that one criterion for the selection of animals in the study, was non-treatment (non-drenching) of goats for the previous year. Thus results of this study seem to indicate that worms are generally not overwhelming 
in the east of Namibia, or else the animals have been selected naturally for the ability to withstand worms, or both.

Over the past few decades it has become conventional for helminthologists to base worm management strategy largely on use of chemicals in such a way that worms are practically excluded as a factor in animal production. However, they lost sight of the fact that methods such as strategic drenching at a time when there are few worms in refugia, or drenching animals before they are moved to uninfected, or lightly infected pasture, strongly select for drug resistance. Furthermore, such methods require routine drenching of all the animals in the flock or herd, and/or facilities such as a variety of separate paddocks-approaches that require resources unavailable to most if not all communal farmers.

Fortunately, because worms are grossly over-dispersed in any given host population (Barger 1985), only a small minority of animals is badly affected in most outbreaks of worm infection. Therefore, a practical approach is to treat only the stragglers that are unable to withstand heavy worm challenge unaided. Faecal worm egg counts are impractical because all individuals need to be tested to identify the few that are heavily infected, and this facility is seldom readily available to all resource-poor farming communities. However, recently Malan \& Van Wyk (1992), Van Wyk, Malan \& Bath (1997) and Malan, Van Wyk \& Wessels (2001) developed and refined the FAMACHAC system whereby haemonchosis is evaluated clinically according to the colour of the ocular mucous membrane, which varies from nearly red in the healthy animals to practically white in those that are terminally anaemic. The system was particularly thoroughly tested in sheep (Van Wyk \& Bath 2002), but also in goats of resourcepoor farmers (Vatta et al. 2001, 2002). Very importantly, it was found that even poorly literate persons are able to apply the FAMACHAC system to good effect.

In conclusion, therefore, it is recommended that the FAMACHAC system is introduced through proper training to the resource-poor farmers of eastern Namibia. It is easy to apply and enables the farmer with very small financial outlay to salvage animals badly affected by haemonchosis and possibly other haematophagus gastrointestinal parasites. The system appears to fit in well with traditional African approach to deal with disease in animals, by treating only the individuals that are obviously affected. In the process both costs and selection for anthelmintic resistance are greatly reduced.

\section{ACKNOWLEDGEMENTS}

This study was sponsored by the University of Namibia Research and Publication Fund and the Ministry of Agriculture Water and Rural Development. Dr R. Hilbert and coworkers at the regional veterinary laboratory in Grootfontein carried out the coprological analysis. The cooperation of communal farmers in Okakarara district is acknowledged. The authors are grateful for valuable criticism from the reviewers of this journal.

\section{REFERENCES}

AMEH, J.A., EGWU, G.O. \& TIJJANI, A.N. 2000. Mortality in sahelian goats in Nigeria. Preventive Veterinary Medicine, 44:107-111.

ANONYMOUS. 1996. SAS/STAT User's Guide, ver. 6, $4^{\text {th }}$ ed., vol. 2, Cary, NC: SAS Institute Inc.

AROSEMENA, N.A.E., BEVILAQUA, C.M.L., MELO, A.C.F.L. \& GIRAO, M.D. 1999. Seasonal variation of gastrointestinal nematodes in sheep and goats from semi-arid area in Brazil. Revue de Medicine Veterinaire, 150:873-876.

BARGER, I.A. 1985. The statistical distribution of trichostrongylid nematodes in grazing lambs. International Journal of Parasitology, 15:645-649.

BARTON, N.J. 1983. Development of anthelmintic resistance in nematodes from sheep in Australia subjected to different treatment frequencies. International Journal for Parasitology, 13:125-130

BIGGS, H.C. \& ANTHONISSEN, M. 1982. The seasonal incidence of helminth parasites and of Oestrus ovis in karakul sheep in the Kalahari region of South West Africa/Namibia. Onderstepoort Journal of Veterinary Research, 49:73-77.

BLITZ, N.M. \& GIBBS, H.C. 1972. Studies on the arrested development of Haemonchus contortus in sheep. II. Termination of arrested development and the spring rise phenomenon. International Journal for Parasitology, 2:13-22.

BOERSEMA, J.H. \& PANDEY, V.S. 1997. Anthelmintic resistance of trichostrongylids in sheep in the highveld of Zimbabwe. Veterinary Parasitology, 68:383-388.

CONNOR, R.J., MUNYUKU, A.P., MACKYAO, E. \& HALLIWELL, R.W. 1990. Helminthosis in goats in southern Tanzania: investigations on epidemiology and control. Tropical Animal Health and Production, 22:1-6.

DONKIN, E.F. \& BOYAZOGLU, P.A. 2000. Milk production from goats for households and small-scale farmers in South Africa, in Proceedings of the $7^{\text {th }}$ International Conference on Goats, Tours/Poitiers, France: 324-326.

GARCIA-PEREZ, A.L., HURTADO, A., OREGUI, L.M. \& JUSTE, R.A. 2002. Effects of a second annual strategic anthelmintic treatment in dairy sheep in Northern Spain. Small Ruminant Research, 43:121-126.

HUART, A., DUNGU, K., MATATU, B. \& SCHANDEVYL, P. 1993. Verminoses gastro-intestinales chez la chevre de race locale au Zaire-importance de l'infestation ainsi que du traitement sur la productivite. Etudes et Syntheses de I'IEMVT, 42:632-644.

KUMBA, F.F., UNDI, M., KATJIVENA, H., KAUTA, G., HENGUA, A. \& TJITEERE, F. 2000. Husbandry practices that predispose small ruminants to parasitic gastrointestinal 
infestation on communal farms in eastern Namibia. Bulletin of Animal Health and Production in Africa, 48:192-198.

KUSILUKA, L.J.M., KAMBARAGE, D.M., HARRISON, L.J.S., DABORN, C.J. \& MATTHEWMAN, R.W. 1998. Causes of morbidity and mortality in goats in Morogoro district, Tanzania: The influence of management. Small Ruminant Research, 29:167-172.

LENTNER, M. \& BISHOP, T. 1993. Randomized complete block designs, in Experimental Design and Analysis, $2^{\text {nd }}$ ed., edited by M. Lentner \& T. Bishop. Blacksburg: Valley Book Co.

MALAN, F.S. \& VAN WYK, J.A. 1992. The packed call volume and colour of the conjunctivae as aids for monitoring Haemonchus contortus infection in sheep, in Proceedings of the South African Veterinary Association Biennial National Veterinary Congress, 7-10 Sept., Grahamstown.

MALAN, F.S., VAN WYK, J.A. \& WESSELS, C.D. 2001. Clinical evolution of anaemia in sheep: Early trials. Onderstepoort Journal of Veterinary Research, 61:165-174.

MUKARATIRWA, S., HOVE, T. \& KYVSGAARD, N. 1997. An abattoir study of seasonal fluctuations of adult and larval stages of Haemonchus contortus in sheep in Zimbabwe. Bulletin of Animal Health and Production in Africa, 45:165168

NDAO, M., BELOT, J., ZINSSTAG, J. \& PFISTER, K. 1995. Epidemiology of gastrointestinal helminthiasis in small ruminants from a tree-cropping pasture system in Senegal. Veterinary Research, 26:132-139.

NUVOR, S.V., ASSOKU, R.K.G. \& AGYEI, A.D. 1997. Peri-parturient rise in faecal nematode egg counts in Djallonkex Nungua Blackhead crosses in the forest zones of Ghana. Bulletin of Animal Health and Production in Africa, 45:169171.

PANDEY, V.S., NDAO, M. \& KUMAR, V. 1994. Seasonal prevalence of gastrointestinal nematodes in communal land goats from the highveld of Zimbabwe. Veterinary Parasitology, 51: 241-248.

POMROY, W.E. 1985. Research on parasitism in goats, in Proceedings of a course in Goat Husbandry and Medicine, Massey University. Veterinary Continued Education, 106: 96-104.

PUGH, D.G., HILTON, C.D. \& MOBINI, S.M. 1998. Control programs for gastrointestinal nematodes in sheep and goats. Compendium on Continued Education for the Practising Veterinarian, Supplement, 20:112-115.

RADOSTITS, O.M., BLOOD, D.C. \& GAY, C.C. 1994. Diseases caused by helminth parasites, in Veterinary Medicine: A textbook of diseases of cattle, sheep, pigs, goats and horses, $8^{\text {th }}$ ed., edited by O.M. Radostits, D.C. Blood \& C.C. Gay. Balliere Tindall: London.
ROWLANDS, D.T. 1993. Anthelmintic resistance-can science win? British Veterinary Journal, 149:117-119.

REINECKE, R.K. 1983. Veterinary Helminthology. Durban \& Pretoria: Butterworths.

URQUHART, G.M., ARMOUR, J., DUNCAN, J.L., DUNN, A.M. \& JENNINGS, F.N. 1996. Veterinary Parasitology, $2^{\text {nd }}$ ed., Oxford: Blackwell Science Ltd.

VAN WYK, J.A. 2001. Refugia-overlooked as perhaps the most potent factor concerning the development of anthelmintic resistance. Onderstepoort Journal of Veterinary Research, 68:55-67.

VAN WYK, J.A. \& BATH, G.F. 2002. The FAMACHAC system for managing haemonchosis in sheep and goats by clinically identifying individual animals for treatment. Veterinary Research, 33:509-529.

VAN WYK, J.A., MALAN, F.S. \& BATH, G.F. 1997. Rampant anthelmintic resistance in sheep in South Africa-what are the options? in Managing Anthelmintic Resistance in Endoparasites by J.A. VAN WYK \& P.C. VAN SCHALKWYK. Workshop held at the $16^{\text {th }}$ International Conference of World Association for Advancement of Veterinary Parasitology, 10-15 August 1997, Sun City, South Africa: 51-63.

VAN WYK, J.A., BATH, G.F. \& MALAN, F.S. 1998. The need for alternative methods to control nematode parasites of ruminant livestock in South Africa. World Animal Review: The FAO Journal on Animal Health, Production and Products: 30-33.

VAN WYK, J.A., STENSON, M.O., VAN DER MERWE, J.S., VORSTER, R.J. \& VILJOEN, P.G. 1999. Anthelmintic resistance in South Africa: surveys indicate an extremely serious situation in sheep and goat farming. Onderstepoort Journal of Veterinary Research, 66:273-284.

VASSILEV, G.D. 1995. Control of haemonchosis in sheep by strategic treatment with closantel. Zimbabwe Veterinary Journal, 26:33-60.

VATTA, A.F., LETTY, B.A., VAN DER LINDE, M.J., VAN WIJK, E.F., HANSEN, J.W. \& KRECEK, R.C. 2001. Testing for clinical anaemia caused by Haemonchus spp. in goats farmed under resource-poor conditions in South Africa using an eye colour chart developed for sheep. Veterinary Parasitology, 99:1-14.

VATTA, A.F., KRECEK, R.C., LETTY, B.A., VAN DER LINDE, M.J., GRIMBEEK, R.J., DE VILLIERS, J.F., MOTSWATSWE, P.W., MOLEBIEMANG, G.S., BOSHOFF, H.M. \& HANSEN, J.W. 2002. Incidence of Haemonchus spp. and effect on haematocrit and eye colour in goats farmed under resource-poor conditions in South Africa, Veterinary Parasitology, 103:119-131.

WALLER, P.J. 1999. International approaches to the concept of integrated control of nematode parasites of livestock. International Journal for Parasitology, 29:155-164. 